the importance of the discovery in its bearing on the antiquity of the stone age in America; but it is scarcely necessary to say that identity in type is not an infallible indication of contemporaneity in dating, and in default of support from geological evidence, identities with European implements previously recognised in the south-west have carried little weight in argument.

\section{A Remarkable Whale from Japan}

Prof. Kyosuke Hirasaka, Department of Zoology, Taihoku Imperial University, Formosa, informs us that he has recently received a letter and a photograph from Mr. T. Iwasaki, chief meteorologist at Ishigaki-jima Observatory $\left(124^{\circ} 10^{\prime}\right.$ E., $24^{\circ} 30^{\prime}$ N.), one of the main islands of the Sakishima Group in the Riukiu Archipelago, describing a marine animal caught off Ishigaki-jima and brought ashore by fishermen on March 8, 1935. From the characteristic form of head and lower jaw, and also its size, nearly $8 \mathrm{ft}$. long, Prof. Hirasaka believes that it might be a

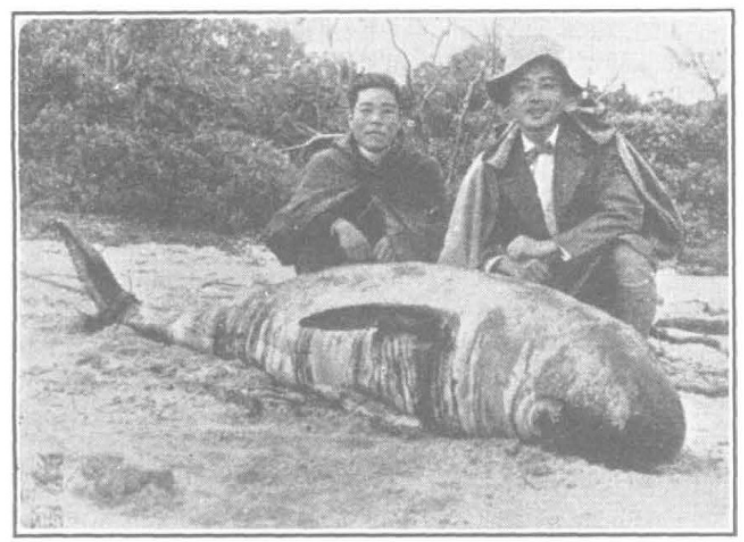

FIG. 1.

pigmy sperm-whale, Kogia breviceps. The only further information available is that it was a dark-skinned animal, and its flesh was of a reddish hue. Prof. Hirasaka points out that this whale was already known from California (Gill, Amer. Naturalist, 1871), as well as in its natural home, the Indian and Southern Oceans, and Mr. Francis C. Fraser, of the British Museum (Natural History), informs us that Van Beneden and Gervais, in their "Ostéographie des Cétacés" (1880), describe and figure a specimen of Kogia which was received from Japan.

\section{Future of Steam Propulsion}

IN the eighth Thomas Lowe Gray Lecture entitled "The Future of Steam Propulsion" and read before the Institution of Mechanical Engineers on January 10, Mr. John Johnson, chief engineer of steamship services, Canadian Pacific Railway, gave it as his opinion that, for such powers as are necessary for ship propulsion, steam plant will ultimately prove to be unsurpassed in reliability, durability and smoothness of working. A fow years ago, the Diesel engine was rapidly gaining in popularity; but, with the improvements already made and likely to appear in the near future, the position is being reversed. It is essential, of course, that the cruder forms of boiler, engine and auxiliary machinery be discarded and be replaced by a system in which each individual part is pre-eminently fitted to give the most efficient service. Boilers in service in the older ships gave an evaporation of $140 \mathrm{lb}$. of steam per hour per ton weight at an efficiency of 80-82 per cent; with improved water-tube boilers and preheaters, the corresponding figures are anticipated to be $750 \mathrm{lb}$. and 90 per cent. To reduce costs of cleaning and repairs, Mr. Johnson looks forward to the use of de-aerated water being accepted as fundamentally necessary in boilers, just as a lubricant is in bearings. Equally effective improvements are suggested in the case of steam turbines, condensers and auxiliary plant.

THE long life of turbines, their relative freedom from wear and repair, and the fact that they require no internal lubrication give them an initial advantage over their rivals, and Mr. Johnson proposed that it would be possible to operate a system with a working pressure of $500 \mathrm{lb}$. per square inch, and an initial temperature of $900^{\circ} \mathbf{F}$. giving 7 per cent wetness at exhaust. With a boiler efficiency of 90 per cent, and $29 \mathrm{in}$. vacuum, the fuel consumption would be as low as $0.48 \mathrm{lb}$. of oil per shaft horse-power per hour. To obtain the most favourable results, the author pleads for co-ordination between the several interested parties - the coal industry and the individual firms manufacturing boilers, engines and other units-to promote improvements. It is, he says, the lack of this close co-operation that has retarded the full development of the steam engine.

\section{Steam, Oil-Electric and Electric Rail Tractors}

ONE of the main purposes of a railway is to transport the products of industry from the place where they are produced to the place where they are consumed. In passenger transportation, a service is performed in conveying the passenger from his starting point to his destination. To serve the needs of a country, a certain number of units of transportation (measured in ton-miles and passenger miles) must be produced every year by the transport system. A discussion of this problem is given by Mr. A. M. Wright in a paper published in the Journal of the Institution of Electrical Engineers of December. The principal competitors of the electric tractor are the steam locomotive and the oil-electric tractor. It has to be remembered that it is not sufficient for a transport system to be capable of producing a given number of ton-miles a year. It is often essential that the units of transportation be produced very rapidly. To take advantage of the superior performance of electric tractors, large capital expenditure for track equipment and substations is required.

Mr. WRIGHT shows that there is a permissible economic capital expenditure for electrification in pence per ton-mile carried per annum. He works out a hypothetical example of a transport system capable of handling various tonnages of goods traffic. The costs of equipping the track for electric working 